\title{
Agrobacterium-Mediated Cassava Transformation For The Asian-elite Variety KU50
}

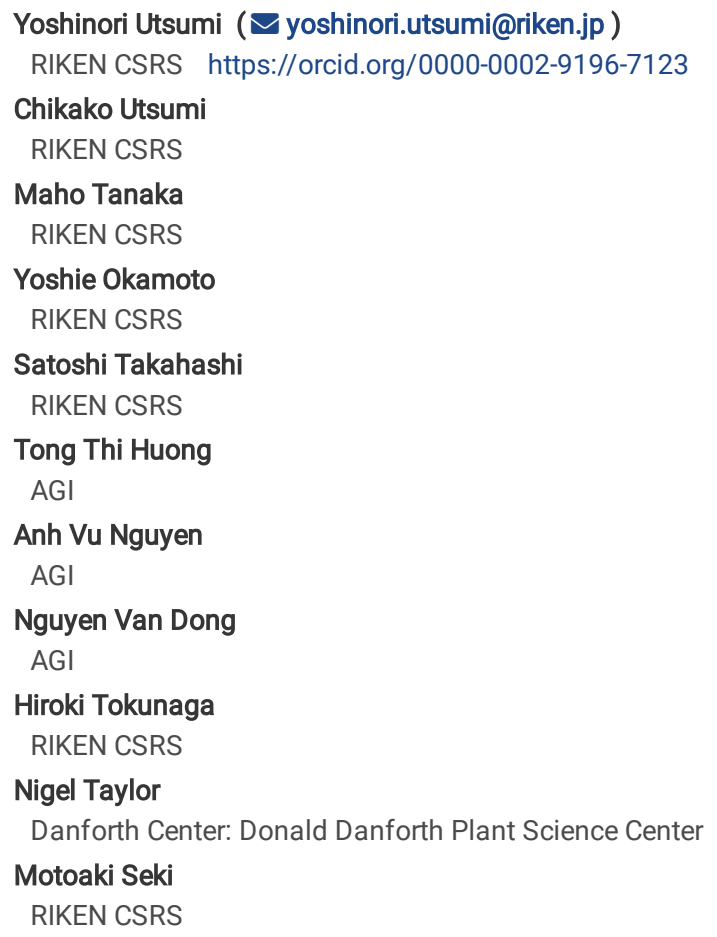

Version of Record: A version of this preprint was published at Plant Molecular Biology on November 26th, 2021. See the published version at https://doi.org/10.1007/s11103-021-01212-1. 


\section{Abstract}

Agrobacterium-mediated cassava transformation via friable embryogenic calli (FEC) has allowed the robust production of transgenic cassava. So far, transformation has been performed mostly for the model cassava variety 60444 and African varieties due to their good production of, and regeneration from, embryogenic tissues. It is important to develop transformation methods for elite Asian cassava varieties to meet changing needs within one of the world's major cassava production areas. To date, however, a suitable transformation method for the Asian elite variety Kasetsart 50 (KU50) has not been developed. Here, we report a transformation method for KU50, the cultivar with the highest planting area in Thailand and Vietnam. In cassava transformation, the preparation of FEC as the target tissue for transgene integration is a key step. FEC induction from KU50 was improved by the use of media with reduced nutrients and excess vitamin B1, and somatic embryo and plant regeneration optimized by manipulation of naphthalene acetic acid (NAA) and benzylamino purine (BAP). The transformation efficiency for KU50 was 22\%, at approximately half of that of 60444 (45\%). Transcriptome analysis indicated that expression of genes related to cell wall loosing was upregulated in FEC from KU50 compared with 60444 , indicating cell wall production and assembly was out of balance in the Asian variety. The transformation system for KU50 reported here will contribute to molecular breeding of cassava plants for Asian farmers by transgenic and genome-editing technologies.

\section{Key Messages}

Cassava genetic transformation has been mostly reported for African cassava varieties but not for Asian varieties. This is the first report of cassava transformation for Asian elite variety using friable embryogenic calli.

\section{Introduction}

Cassava (Manihot esculenta Crantz) is grown across the tropics and sub-tropical regions for production of its starchy tuberous roots. It provides an important source of daily calories for 100 s of millions for people and plays a critical role in global food security and rural economies (Balat and Balat 2009). The acceleration of cassava breeding is desirable to meet demands of the increasing population and evolving market needs (Malik et al. 2020). However, conventional breeding based on sexual hybridization is challenging in cassava due to its high degree of genetic heterozygosity, inbreeding depression, asynchronous flowering, self-incompatibility, and low fruit set in some varieties (Ceballos et al. 2004; Liu et al. 2011). For semi-woody, vegetatively propagated species such as cassava, genetic transformation and genome editing can also provide fundamental insights into plant biology and methods for rapid crop improvement through integration of novel traits without altering the genetic background of elite, farmer-preferred parent material (Altpetera et al. 2016). Recently, genome editing by CRISPR-Cas9 technology has been reported in cassava (Hummel et al. 2018; Odipio et al. 2017; Seki et al. 2018) For both gene editing and conventional transformation, the preferred methods involve Agrobacterium-mediated delivery of molecular sequences into disorganised embryogenic callus with subsequent regeneration of somatic embryos and their germination to produce plants.

The induction of friable embryogenic calli (FEC) is a key step for production of target tissues for cassava transformation and has been established as a reproducible method for cassava genetic transformation (Chavarriaga-Aguirre et al. 2016). FEC are generated from somatic embryos induced on media supplemented with the potent auxin picloram (Taylor et al. 1996; Bull et al. 2009; Taylor et al. 2012). Improvement of the FEC induction process has been achieved by addition of tyrosine and moxolactam (Chauhan at el. 2015; Nyaboga et al 2015) and optimization of nutrient conditions in the culture media (Utsumi et al. 2017). Despite these advances production of transgenic cassava remains limited to a relatively small range of varieties, mostly of African origin

In this study, we report the establishment of Agrobacterium-mediated transformation for the Asian elite cassava variety, Kasetsart 50 (KU50). Currently, KU50 is cultivated in Thailand, Vietnam, Indonesia, Cambodia, Myanmar, and the Philippines. This variety has been cultivated in more than 1 million hectares of Thailand and Vietnam alone (Malik et al. 2020).

\section{Materials And Methods}

\section{Plant materials and growth conditions}

Cassava cultivars Kasetsart 50 (KU50) and 60444 were obtained from the in vitro germplasm collection of the International Center for Tropical Agriculture (CIAT), Cali, Colombia. In vitro plantlets were maintained by sub-culturing microcuttings every 4-8 weeks on Murashige and Skoog basal salts (Murashige and Skoog 1962) (MS) supplemented with $20 \mathrm{~g} / \mathrm{L}$ sucrose, $2 \mu \mathrm{M} \mathrm{CuSO}_{4}, \mathrm{MS}$ vitamins and $3 \mathrm{~g} / \mathrm{L}$ gelrite. Media was adjusted to $\mathrm{pH} 5.8$ using $1 \mathrm{M} \mathrm{KOH}$ before autoclaving for $20 \mathrm{~min}$ at $121 \circ \mathrm{C}$ (Supplementary table 1). Plantlets were cultured in plastic vessels containing $100 \mathrm{~mL}$ media and incubated at $28^{\circ} \mathrm{C}$ under a $16 \mathrm{~h}$ light/8h dark photoperiod at $40 \mu \mathrm{mol} \mathrm{m}^{-2} \mathrm{~s}^{-1}$ intensity.

Axillary buds (AB) produced from nodal stems of in vitro plantlets of KU50 and 60444 were used as explants for the induction of organized embryogenic calli (OEC). In order to induce the formation of the $A B$, all leaves were removed from the in vitro plantlets (8-10 cm in size) and $20-30 \mathrm{~mm}$ stem sections carrying single nodes excised. The single-nodal-stem fragments were placed horizontally on cassava axillary medium (CAM) consisting of MS medium supplemented with $10 \mathrm{mg} / \mathrm{L}$ BAP (Bull et al. 2009) and incubated for 4-7 days at 28.C in the dark. Swollen ABs were excised from the stem sections using a sterile syringe, and incubated on callus induction medium (CIM) consisting of MS medium supplemented with $12 \mathrm{mg} / \mathrm{L}$ of picloram for 2 weeks at $28 \circ \mathrm{C}$ in the dark. The number of $A B$ that formed the OEC was counted at two weeks after culturing on CIM. When multiple OEC were observed from one axillary bud, number of OEC induced was counted as one. The OEC produced were excised and subcultured onto media containing Driver and Kuniyuki Walnut basal salts (DKW) (Driver and Kuniyuki 1984), supplemented with $20 \mathrm{~g} / \mathrm{l}$ sucrose, MS vitamins and $12 \mathrm{mg} / \mathrm{L}$ picloram (Chauhan et al. 2015). After culture for 2 weeks at $28^{\circ} \mathrm{C}$ in the dark, OEC were transferred to FEC induction media (FIM) consisting of Gresshoff and Doy basal salts (Gresshoff and Doy 1974) (GD) supplemented with MS vitamins and reduced nutrients, excess vitamin B1 and $12 \mathrm{mg} / \mathrm{L}$ picloram as described by Utsumi et al. (2017) (Supplementary table 1). The OEC were cultured 
on FIM for 2-3 weeks at $28^{\circ} \mathrm{C}$ in the dark. Fine FEC as isolated from non-embryogenic tissue using fine tweezers and transferred to fresh FIM. The isolated FEC were stringently selected in this manner every 2-3 weeks for a maximum of six months to produce homogenous colonies of FEC. The number of $A B$ that formed the FEC was estimated at six months after culturing on FIM. When multiple FEC were induced from OEC induced from one bud, number of FEC induced was counted as one.

Agrobacterium -mediated transformation and plant regeneration

The pMDC111 binary plasmid vector (Curtis and Grossnikaus 2003) was used for transformation of KU50 and 60444 FEC tissues. The mGFP6 reporter gene (Born and Pfeifer. 2019) in pMDC111 was under control of the enhanced 35S promoter. A DNA sequence of enhanced 35S promoter was obtained by PCR using the pCAMBIA1300 as the template using the primer pair: (Forward; 5'- GGGGACAAGTTTGTACAAAAAAGCAGGCT ATGGTGGAGCACGACACTCTCG-3') and (Reverse; 5'- GGGGACCACTTTGTACAAGAAAGCTGGGT GGAGAGATAGATTTGTAGAGAG-3'). A DNA fragment of enhanced 35S promoter was cloned into the pDONR/Zeo vector by the BP clonase reaction (ThermoFisher). A DNA fragment in the pDONR/Zeo was ligated into the pMDC111 vector by the LR clonase reaction (ThermoFisher). pMDC111 vector with enhanced 35S promoter::mGFP6 was electroporated into Agrobacterium tumefaciens strain LBA4404 (Hood et al. 1986) and transformation of FEC was performed as described by Utsumi et al. (2017).

After co-culture, inoculated FEC were subcultured onto FIM containing $200 \mathrm{mg} / \mathrm{L}$ carbenicillin and $5 \mathrm{mg} / \mathrm{L}$ hygromycin and cultured for one week at $28^{\circ} \mathrm{C}$ under continuous dark conditions. Tissues were then subcultured on FIM containing $10 \mathrm{mg} / \mathrm{L}$ hygromycin and $200 \mathrm{mg} / \mathrm{L}$ carbenicillin and cultured for one week. A third selection was subsequently performed on FIM supplemented with $20 \mathrm{mg} / \mathrm{L}$ hygromycin and $200 \mathrm{mg} / \mathrm{L}$ carbenicillin for one week. Regeneration of cotyledon-stage embryos was achieved by transferring FEC colonies to SE emerging medium (MSN) consisting of MS salts supplemented with 1 mg/L NAA, $100 \mathrm{mg} / \mathrm{L}$ carbenicillin and $20 \mathrm{mg} / \mathrm{L}$ hygromycin and cultured for a maximum of four months. Cotyledon-stage embryos were selected and subcultured onto cassava elongation medium (CEM) composed of MS medium amended with $0.4 \mathrm{mg} / \mathrm{L} \mathrm{BAP,} 100 \mathrm{mg} / \mathrm{L}$ carbenicillin and $20 \mathrm{mg} / \mathrm{L}$ hygromycin. Embryos were cultured on CEM until shoot and roots were produced. Regenerated plantlets were maintained on MS media supplemented within $50 \mathrm{mg} / \mathrm{L}$ of carbenicillin and $5 \mathrm{mg} / \mathrm{L}$ of hygromycin.

\section{Establishment and growth of plants in the greenhouse}

In vitro plants were transferred to the greenhouse. One stem cutting per regenerated plant line was grown in $100 \mathrm{~mL}$ MS medium solidified with $0.5 \%$ (w/v) agarose in plastic vessel for two months at $28^{\circ} \mathrm{C}$. The medium was then carefully removed to prevent damage to the roots, and plants cultivated for about 2 weeks in plastic vessel including distilled water at $28^{\circ} \mathrm{C}$ under cool-white fluorescent light at the $40 \mu \mathrm{mol} \mathrm{m}^{-2} \mathrm{~s}^{-1}$ intensity. Plantlets were transferred to soil consisting of a mixture of black soil, coconut peat and vermiculite at a ratio of 2:1:2 in pot and maintained within plastic tray covered by plastic wrap for 21 days in a greenhouse maintained at $28^{\circ} \mathrm{C}$ under natural light at Yokohama in Japan and supplemental lighting with an approximate light/dark cycle of $12 / 12$ h. The plastic wrap was removed gradually and plants grown on the open bench in a greenhouse maintained at $28^{\circ} \mathrm{C}$ under natural light at Yokohama in Japan and supplemental lighting with an approximate light/dark cycle of $12 \mathrm{~h} / 12 \mathrm{~h}$.

\section{Microscopic observation}

The observation of the GFP fluorescence was performed on the first to third leaves from top of plantlets maintained in MS media and on roots of plants grown in soil. Imaging was done with the M165 FC fluorescence microscope (Leica, Wetzlar, Germany) equipped with a cooled CCD camera VB-7010 (Keyence, Osaka, Japan), 10x eyepiece, plan apo 2x Corr. objective or objective planapo 0.63x M series (Leica, Wetzlar, Germany). Images were taken using illumination with excitation laser line $486 \mathrm{~nm}$, with emission filter $518 \mathrm{~nm}$.

\section{Detection of GFP and HPT gene}

The first or second youngest, healthy leaves of in vitro plants were used for genomic DNA preparation. Leaf samples were disrupted using a ShakeMaster and zirconia beads (Hirata Corporation), and genomic DNA extracted according to the protocol of Wizard Magnetic 96 DNA Plant System (Promega) using BIOMEK (Beckman Coulter). Genomic DNA was stored at $-80^{\circ} \mathrm{C}$ until further use.

The presence of $g f p$ and $h p t$ transgenes in transgenic cassava lines was confirmed by PCR analysis using KOD-FX Neo (Toyobo) and gene-specific primers. The thermocylcer parameters used for amplification of $\mathrm{gfp}$ and $h p t$ were $95^{\circ} \mathrm{C}$ for $5 \mathrm{~min} ; 35 \mathrm{cycles}$ of $98^{\circ} \mathrm{C}$ for $10 \mathrm{sec}, 68^{\circ} \mathrm{C}$ for $30 \mathrm{sec}$, and $68^{\circ} \mathrm{C}$ for $30 \mathrm{sec}$; and a final 5-min extension at $68^{\circ} \mathrm{C}$. PCR products were analyzed by gel electrophoresis on a $1 \%(\mathrm{w} / \mathrm{v})$ agarose gel stained with ethidium bromide. The primers used for PCR were as follows: GFP, 5'- CACTGGAGTTGTCCCAATTCTTGTTG-3' (forward) and 5'-CATGCCATGTGTAATCCCAGCA-3' (reverse); HPT, 5'TCACCGCGACGTCTGTCGAG-3' (forward) and 5'-GCTCCATACAAGCCAACCAC-3' (reverse).

\section{Total RNA extraction from FEC samples}

RNA was extracted from homogenous FEC tissues of KU50 and 60444. Total RNA was extracted from at least 100 mg FW (fresh weight) per biological replicate as described by Utsumi et al. (2017) and then stored at $-80^{\circ} \mathrm{C}$ until use.

\section{Oligo-microarray analysis of gene expression}

Total RNA was used to evaluate gene expression levels with a cassava DNA oligo-microarray comprising more than 30,000 probes as described by Utsumi et al. (2016). Gene expression data represent four independent biological replicates per FEC from KU50 and 60444. A total of eight microarray data sets were analyzed with GeneSpring GX (Agilent Technologies, USA). Specifically, the data underwent an analysis of Student's t-test with a Benjamini-Hochberg (BH) false discovery rate (FDR) to identify differentially expressed genes (DEGs) among two data sets. The oligo-DNA microarray data were deposited in the NCBI Gene Expression Omnibus (GEO) database and are accessible via a GEO Series accession number GSE169685. 


\section{Southern blot analysis to determine T-DNA copy number}

Genomic DNA was prepared by the CTAB method (Doyle and Doyle 1987). Homogenized leaf samples were prepared by cryogenically grinding tissue in a multibead shaker after chilling in liquid nitrogen. One gram of homogenized tissue was incubated in $6 \mathrm{ml}$ of $2 \times \mathrm{CTAB}\{2 \% \mathrm{CTAB}, 100 \mathrm{mM}$ Tris- $\mathrm{HCl}$ ( $\mathrm{pH} 8.0$ ), 1.4 $\mathrm{M} \mathrm{NaCl}, 20 \mathrm{mM} \mathrm{EDTA}\}$ at $55^{\circ} \mathrm{C}$ for 60 minutes. After centrifuging the homogenate for $20 \mathrm{~min}$ at $2,800 \mathrm{xg}$, the supernatant was transferred to a new tube and gently mixed in 1 volume of chloroform/isoamyl alcohol (24:1) for $20 \mathrm{~min}$ at room temperature, followed by centrifugation for $20 \mathrm{~min}$ at $2,800 \mathrm{x} \mathrm{g}$ to separate the phases. The aqueous upper phase was transferred to a new tube and mixed in 0.1 volume of $10 \% \mathrm{CTAB}$ solution ( $10 \% \mathrm{CTAB}, 0.7 \mathrm{M} \mathrm{NaCl)}$ and $1 \mathrm{volume}$ of chloroform/isoamyl alcohol (24:1) and incubated for $10 \mathrm{~min}$ at room temperature. The aqueous upper phase was collected by centrifugation for $30 \mathrm{~min}$ at $2,800 \mathrm{x}$. The DNA was precipitated by adding 1 volume of CTAB precipitation buffer $\{1 \% \mathrm{CTAB}, 50 \mathrm{mM}$ Tris- $\mathrm{HCl}$ (pH 8.0$), 10 \mathrm{mM} E D T A\}$ to the aqueous upper phase collected and incubated at room temperature for overnight. The DNA was collected by centrifugation at $5,000 \times \mathrm{g}$ for $10 \mathrm{minutes}$ and dissolved in $100 \mu \mathrm{l}$ TE buffer $\{10 \mathrm{mM}$ Tris- $\mathrm{HCl}(\mathrm{pH} 8.0), 1 \mathrm{mM}$ EDTA $\}$. Three microlitres of RNase solution $\mathrm{A}(10 \mathrm{mg} / \mathrm{mL})$ was added to the DNA solution and incubated at $37^{\circ} \mathrm{C}$ for $30 \mathrm{~min}$. Southern blot analysis was carried out according to the standard protocol (Southern 2006). Five micrograms of genomic DNA was incubated for 20 hours with 30 units of HindIII, which cuts the T-DNA once, and subjected to electrophoresis on a $0.8 \%$ agarose gel. The agarose gel was soaked in depurination solution $(0.2 \mathrm{~N} \mathrm{HCl})$ for 10 minutes at room temperature and denatured in denaturation solution $(1.5 \mathrm{M} \mathrm{NaCl}, 0.5 \mathrm{M} \mathrm{NaOH})$ for 30 min. The agarose gel was then soaked in neutralization solution $\{1.5 \mathrm{M} \mathrm{NaCl}, 0.5 \mathrm{M}$ Tris $-\mathrm{HCl}(\mathrm{pH} 7.5)\}$ for 30 min. The fractionated DNA in agarose gel was transferred to a positively charged nylon membrane using capillary blotting in $20 \times \mathrm{SSC}\{(3 \mathrm{M} \mathrm{NaCl}$ in $0.3 \mathrm{M}$ sodium citrate (pH 7.0)\}. The hybridization probe specific to hpt of T-DNA was DIG-dUTP-labeled using a PCR DIG probe synthesis kit (Roche Diagnostics GmbH, Germany) and used for the hybridization experiment according to the manufacturer's instructions.

\section{Statistical Analyses}

All data except for transcriptome data are represented as means \pm SD from at least three biological experiments. Statistical analysis of means was assessed by analysis of variance using StatPlus 5 pro (AnalystSoft Inc. USA). Data for the optimization experiments underwent a one-way ANOVA and differences among means were analyzed by Scheffe's method at a 95\% confidence level ( $p \leq 0.05)$ with StatPlus 5 pro (AnalystSoft Inc. USA) (Bother 1967).

\section{Results}

\section{Optimization of OEC and FEC induction, and shoot regeneration in KU50}

We compared the induction efficiency for OEC and FEC from KU50 and 60444 determined per the number of starting axillary bud explants as described by Utsumi et al. (2017) (Fig. 1). OEC were induced from axillary buds (AB) of KU50 within 2 weeks culture on MS medium supplemented with 12 mg/L picloram (CIM). The morphology of OEC produced from KU50 (Fig. 2C) was similar to that seen from 60444 (Fig. 2a). The OEC induction efficiency from AB after 2 weeks on CIM ranged from 47-67\% with an average of $60 \%$ in KU50, which was slightly lower than that of 60444 which averaged $71 \%$ (Table 1 ). The efficiency of FEC induction from OEC was assessed after 6 months culture on FIM. FEC induction was less efficient at $12 \%$ in KU50, compared to $50 \%$ for 60444 (Table 1). The morphology of FEC generated from KU50 was similar to that produced by 60444 (Fig. 2b, d), but took at least 3 months to produce, compared to only one month from 60444 .

Although the basic procedures of cassava transformation employed in the present study were similar to that previously reported, optimization of regeneration conditions was found to be necessary for KU50. We investigated the optimal concentrations of NAA and BAP necessary for stimulating regeneration of cotyledon-stage embryos from FEC and for germination of mature embryos, respectively. Six colonies of FEC from KU50 were cultivated on MS media supplemented with various concentrations of NAA and subcultured every two weeks as shown in Fig. 1a. Cotyledon-stage embryos were formed (Fig. 1b), with the optimal concentration of NAA found to be $1.0 \mathrm{mg} / \mathrm{L}$ (Fig. 1c). The cotyledon-stage embryos produced were incubated on MS media supplemented with various concentrations of BAP and evaluated for the shoot regeneration efficiency over a 2-month period (Fig. 1d, e). The optimal concentration of BAP was found to be $0.4 \mathrm{mg} / \mathrm{L}$ (Fig. 1f), being similar to that reported for 60444 (Bull et al. 2009; Taylor et al. 2012).

\section{Agrobacterium-mediated transformation for KU50}

Agrobacterium-mediated transformation of KU50 followed the process reported for 60444 (Utsumi et al. 2017). To perform the transformation experiments, approximately 100 axillary buds were prepared from approximately 30 two month old in vitro plants. Stems were placed on MS medium containing 10 mg/L BAP to induce swelling of the axillary buds, followed by excision and culture on MS basal medium containing picloram. (Utsumi et al. 2017). OEC production occurred at about $74 \%$ and $64 \%$ per total number of starting axillary buds for 60444 and KU50, respectively (Table 1). OEC produced from axillary buds was incubated on DKW media with $12 \mathrm{mg} / \mathrm{L}$ of picloram for the growth during 2 weeks. In this step, no significant differences in the growth and OEC formation were observed between 60444 and KU50. OEC (2-3 mm in diameter) was manipulated under a microscope using fine tweezers with OEC from one bud arranged as one group on the FIM containing $12 \mathrm{mg} / \mathrm{L}$ picloram to assess efficiency of FEC induction.

FEC can be generated effectively by culturing primary OEC on FIM containing $12 \mathrm{mg} / \mathrm{L}$ picloram. First observation of FEC after culturing on FIM media with picloram was at 4 weeks and 12 weeks in 60444 and KU50, respectively. In KU50, about $1.2 \mathrm{~g}$ of FEC was generated from 100 axillary buds by sequential culturing on FIM for 9 weeks, whereas about $5.4 \mathrm{~g}$ of FEC was generated from 100 axillary buds in 60444 ovr the same period. The type and appearance of FEC generated from KU50 was similar to that from 60444 . However, the lower frequency of production, longer culture period required and lesser amount of FEC produced indicates the lower potential for FEC production in KU590 in comparison to the highly amenable variety 60444 (Table 1 ).

Cassava transformation was carried out using the pMDC111 vector which carried the visual marker including mgfp6 gene. FEC was collected and co-cultured with Agrobacterium suspension (OD600 nm, 0.1). The OD of Agrobacterium suspension did not affect the copy number of T-DNA in transgenic plants or the

Page $4 / 11$ 
transformation process (Taylor et al. 2012). To prevent re-growth of Agrobacterium, careful manipulation of washing process was required. The transformed FEC was evenly spread over FIM with hygromycin and carbenicillin. In KU50, selection on FIM with hygromycin for 3 weeks was not sufficient for full selection of the transgenic calli. Therefore, FEC was spread evenly over MSN medium containing hygromycin and NAA, and subcultured every 21 days to induce formation of cotyledon-stage embryos. Table 2 shows the efficiency of cotyledon-stage embryo production and plantlet formation per $1 \mathrm{~g}$ fresh weight of starting FEC (normalized for the amount of starting tissues used for Agrobacterium co-cultivation). Cotyledon-stage embryos appeared about one month after culturing on MSN with hygromycin and continued over a period of 3 months. Fifty-eight and 151 cotyledon-stage embryos were generated for 60444 and KU50 respectively. Cotyledon-stage embryos were transferred to CEM containing hygromycin and BAP for the induction of shoots. Shoot formation was observed within 1 month at the earlies, with plantlets formed from $22 \%$ of the cotyledon-stage embryos for KU50 (Table 2).

In this study, mGFP6 was used as the selection marker. mGFP6 generates a stronger fluorescence signal due carrying substitutions of ten amino acids from the soluble-modified GFP (smGFP) (Born and Pfeifer. 2019). GFP fluorescence was observed in the process of selection on FIM and plantlet-inducing stage on CEM (Figs 2e and 2f). However, it was found to be difficult to select GFP expressing tissues from transgenic FEC due to autofluorescence from FEC at the early stage after the co-culture with Agrobacterium. Therefore, we evaluated transformation efficiency by confirming GFP florescence in leaf veins and stems of regenerated plants (Table 2). The transformation efficiency (calculated as the number of GFP-positive plantlets per number of cotyledon-stage embryos regenerated from $1 \mathrm{~g}$ of FEC) was $45 \%$ and $22 \%$ for 60444 and KU50, respectively (Table 2). In addition to GFP expression, the transgenic nature of regenerated plants was confirmed by PCR and Southern blotting analyses (Figs. 2n, $0, p$ ). Southern blotting confirmed integration of single copies of the TDNA in 60444 and KU50 transgenic plant lines.

Acclimatizing in vitro cassava plantlets can result in high mortality, due often to damage of the fragile roots. We therefore reduced the agar concentration in MS micropropagation media from $2.0 \%$ to $0.5 \%(\mathrm{w} / \mathrm{v})$ prior to transfer to soil. Using this method, plants with well-developed root systems were transferred from the culture vessel to soil pot without root damage and kept under high humidity. GFP signal was confirmed in plants growing in soil. GFP fluorescence was observed in leaf veins and roots of the transgenic lines (Figs $2 \mathrm{j}$ and $2 \mathrm{l}$ ), with no such signals seen for non-transgenic control plants (Figs $2 \mathrm{~g}$ and $2 \mathrm{~h}$ ).

\section{Lower FEC induction efficiency in KU50 might be due to excess cell-wall loosing and increased stress response compared with 60444}

To compare the physiological status between FEC produced by KU50 and 60444, gene expression analysis was performed by oligo-microarray, using total RNA extracted from these tissues. Using the criteria of FDR $\leqq 0.00005$ by BH method and a two-fold change in expression, 2,213 differentially expressed genes (DEGs) were identified by comparing 60444 and KU50. Among these, 1,287 genes were up-regulated and 926 genes down-regulated in KU50 compared with 60444 (Supplementary Table 2). The DEGs annotated based on the Arabidopsis thaliana genome sequence were functionally classified with agriGO. The GO terms of "cellular component (Supplementary Fig. 1 legend), "molecular function" and "biological process" were significantly enriched (Supplementary Figure 1-5 and Supplementary Table 3-6).

In the "cellular component", the genes with GO terms including "GO:0005618 Cell wall", "G0:0044459 Plasma membrane part" and "GO:0005576 Extracellular region" were enriched among the upregulated genes in FEC from KU50 (Supplementary Fig. 1 and Supplementary Table 3). The following cell wall modification-related genes existed: pectinesterase (PE) which is involved in dimethyl esterification of pectins (Willats et al. 2001), polygalacturonase (Park et al. 2015) that modifies cell wall structure, xyloglucan endotransglucosylase (XTH) which encodes a cell wall-modifying enzyme and expansin which plays an important role in plant cell growth where cell wall loosening occurs (Li et al. 2002). Within "molecular function", the genes with GO terms including "GO:0035251 UDP-glucosyltransferase activity” were upregulated in FEC from KU50 (Supplementary Fig. 2), suggesting that increased stress response through upregulation of several UDP-glucosyltransferases (Rehman et al. 2018) might occur in FEC from KU50 (Supplementary Table 4). The G0 terms enriched in the up-regulated genes in KU50 had "response to abscisic acid" (G0:0009737), "response to osmotic stress" (G0:0006970), "response to oxidative stress" (G0:0006979) and "response to wounding" (GO:0009611) (Supplementary Fig. 3) in the "biological process". The expression of the following genes was increased in KU50 compared with 60444: P5CS2 (AT2G17840) which is involved in proline biosynthesis (Funck et al. 2020), ADC2 (AT4G34710), involved in the first step of polyamine biosynthesis (Urano et al. 2004), ZAT10 (AT1G27730) involved in photooxidative stress response, ERD7 (AT2G17840) involved in remodelling cell membrane lipid composition during cold stress (Barajas-Lopez et al. 2020), chitinase A (AT5G24090) whose expression is induced by various abiotic and biotic stress conditions (Takenaka et al. 2009), SAG14 (AT5G20230) which encodes a glycosylphosphatidylinositol-anchored protein that regulates lignin biosynthesis (Ji et al. 2015), and CYP94B1 (AT5G63450) which is involved in apoplastic barrier formation through suberin biosynthesis (Krishnamurthy et al. 2020) (Supplementary Table 5).

We also compared the genes upregulated in KU50 FEC with genes up- or down-regulated in 60444 FEC in comparison with somatic embryos (SE) (Ma et al. 2015) and the genes upregulated in 60444 grown under FIM (Utsumi et al. 2017) (Table 3). The expression of several upregulated genes in KU50 FEC included PPCK1 and PPCK2 which plays a key role in control of plant metabolism by phosphorylation of phosphoenolpyruvate carboxylase, XTH16 (AT3G23730) which is involved in loosening of cell wall structure, and non-specific phospholipase C4 (NPC4)(AT3G03530 which is important for supply of inorganic phosphate. Finally, diacylglycerol from membrane-localized phospholipids (Peters et al. 2010) was also up-regulated in 60444 grown on CIM with reduced nutrients and excess vitamin B1 (Utsumi et al. 2017) (Table 3). Several upregulated genes in KU50 FEC, such as acetyl-CoA synthetase were also upregulated in fresh 60444 FEC compared with SE (Ma et al. 2015). There were no differences in KU50 FEC with the genes involved in callus induction or repression (Ikeuchi et al. 2013) (Supplementary Table 7) and the DEGs involved in the cell cycle related process (Supplementary Table 8) was not observed.

Although growth of KU50 FEC is likely to be stimulated by the use of media containing auxin, the expression of genes related to abiotic stress responses and loosening the cell wall was upregulated in KU50 in comparison with 60444. It is possible therefore that FEC growth in KU50 might be inhibited by excess cell wall-loosening process in comparison with that of 60444, and result in the observed increased expression of stress response-related genes.

\section{Discussion}


In this study, we developed a system for Agrobacterium-mediated transformation of the Asian elite variety KU50. The use of picloram and limited nutrient media in addition to excess vitamin B1 resulted in increased induction of FEC, while optimization of BAP and NAA improved somatic embryo regeneration from FEC and germination to produce transgenic plantlets. This is the first report for establishment of Agrobacterium-mediated cassava transformation system via FEC for KU50.

Many factors affect genetic transformation efficiency in cassava. Effective induction of FEC is crucial as this acts as effective target tissue for transgene integration (Bull et al. 2011; Chavarriaga-Aguirre et al. 2016; Taylor et al. 2012). Successful induction of SE, the first step in FEC production, in Asian cassava varieties has been reported (Ntui et al. 2015; Saelim et al. 2009), so was not a limiting factor for transformation for KU50. FEC of KU50 was induced during extended culture on FIM. However, the induction efficiency of FEC was 5 times lower in KU50 compared with the model variety 60444 (Table 1 ). We hypothesis that this may be due to imbalance between cell wall production and assembly in KU50 FEC, because the genes related to cell wall loosening process were found to be up-regulated in KU50 FEC (Table 3 and Supplementary Table 3). Cassava transformation has been reported in most cases using FEC induced by culturing on GD media containing picloram (Bull et al. 2009; Taylor et al. 2012; Utsumi et al. 2017), with FEC formation observed after 2 month-incubation on media with picloram. In KU50 FEC, production takes at least 4 months cultivation on FIM media. Further technical improvement is therefore necessary to shorten this time and reduce the potential frequency of somaclonal variation resulting from longer culture durations. In this report, we determined the optimal NAA concentration for regeneration from FEC to cotyledon-stage embryos and for subsequent shoot formation on medium containing BAP. The optimal concentration of NAA and BAP was $1.0 \mathrm{mg} / \mathrm{L}$ (Fig. 1c) and $0.4 \mathrm{mg} / \mathrm{L}$ (Fig. 1f), respectively, in a manner similar to results of transformation using 60444 (Bull et al. 2009).

The transformation efficiency of 60444 and KU50 was $45 \%$ and $22 \%$, respectively. An average 26 transgenic lines per one gram of FEC from 60444 were obtained, whereas 33 transgenic lines per one gram of FEC from KU50 were obtained within 12 months after Agrobacterium inoculation (Table 2). These data align with previous reports, where the number of transgenic lines obtained one gram of FEC was in rage of 22-50 plants (Chetty et al. 2013; Nyaboga et al. 2015; Taylor et al. 2012). The addition of silver nitrate $\left(\mathrm{AgNO}_{3}\right)$ was effective for shoot organogenesis from somatic cotyledons ( $\mathrm{Zhang}$ et al. 2001) and for inhibition of $A$. tumefaciens growth during the selection (Gyves et al. 2010).

The development of a genetic transformation method for KU50 described here will contribute to improvement of key characteristics in this very important Asian cassava cultivar. The use of novel cutting-edge technologies such as CRISPR-Cas 9 can now be applied and contribute to molecular breeding (Altpetera et al. 2016). For example the introduction of the Flowering Locus T gene has been demonstrated to be successful for shortening the breeding time, generation of the transgene-free progenies and production of the amylose-free cassava starch, which is a useful trait for the food and industrial applications of cassava (Bull et al. 2018; Malik et al. 2020). This approach now becomes feasible for KU50 also. Such approaches will contribute to expanding cassava diversity towards food security, commodity diversity, and sustainability for global demands

\section{Declarations}

\section{Data availability}

Novel data generated in this study, including microarray data, have been deposited in the National Center for Biotechnology Information under the accession number GSE169685.

\section{Acknowledgments}

This work was supported by the following funding: Strategic Funds for the Promotion of Science and Technology, EIG CONCERT-Japan 4th Call under the Strategic international Research cooperative Program of the Japan Science and Technology Agency (JST), the Science and Technology Research Partnership for Sustainable Development (SATREPS) in a collaboration between the Japan Science and Technology Agency (JST, JPMJSA1508) and the Japan International Cooperation Agency (JICA), and RIKEN Center for Sustainable Resource Science (CSRS).

\section{Author and Contributors}

YU and MS supervised the experiments, and YU, MS and NJT wrote the manuscript. YU, CU and MT performed the experiments and analyzed the data. ANV, NVD and HT gave the constructive comments. YU, MT and ST performed the transcriptome analysis. CU, YO, MT and TTH managed the plants. NJT gave critical suggestions on methodologies.

\section{References}

1. Altpeter F, Springer NM, Bartley LE, Blechl AE, Brutnell TP, Citovsky V, Conrad LJ, Gelvin SB, Jackson DP, Kausch AP, Lemaux PG, Medford JI, OrozcoCárdenas ML, Tricoli DM, Van Eck J, Voytas DF, Walbot V, Wang K, Zhang ZJ, Stewart CN (2016) Advancing Crop Transformation in the Era of Genome Editing. Plant Cell 28:1510-1520

2. Balat M, Balat $H$ (2009) Recent trends in global production and utilization of bio-ethanol fuel. Appl Energy 86:2273-2282

3. Barajas-Lopez JD, Tiwari A, Zarza X, Shaw MW, Pascual J, Punkkinen M, Bakowska JC, Munnik T, Fujii H (2020) EARLY RESPONSE TO DEHYDRATION 7 Remodels Cell Membrane Lipid Composition During Cold Stress in Arabidopsis. Plant Cell Physiol pcaa139

4. Bother R (1967) On sharpening Scheffe bounds. J Roy Stat Soc 29:110-114

5. Born J, Pfeifer F (2019) Improved GFP variants to study gene expression in Haloarchaea. Front Microbiol 10:1200 
6. Bull SE, Owiti JA, Niklaus M, Beeching JR, Gruissem W, Vanderschuren H (2009) Agrobacterium-mediated transformation of friable embryogenic calli and regeneration of transgenic cassava. Nat Protoc 4:1845-1854

7. Bull SE, Ndunguru J, Gruissem W, Beeching JR, Vanderschuren H (2011) Cassava: constraints to production and the transfer of biotechnology to African laboratories. Plant Cell Rep 30:779-787

8. Bull SE, Seung D, Chanez C, Mehta D, Kuon JE, Truernit E, Hochmuth A, Zurkirchen I, Zeeman SC, Gruissem W, Vanderschuren H (2018) Accelerated ex situ breeding of GBSS- and PTST1-edited cassava for modified starch. Sci Adv 4:eaat6086

9. Ceballos H, Iglesias CA, Pérez JC, Dixon AGO (2004) Cassava breeding: opportunities and challenges. Plant Mol Biol 56:503-516

10. Chavarriaga-Aguirre P, Brand A, Medina A, Prías M, Escobar R, Martinez J, Díaz P, López C, Roca WM, Tohme J (2016) The potential of using biotechnology to improve cassava: a review. In Vitro Cell Dev Biol-Plant 52:461-478

11. Chauhan RD, Beyene G, Kalyaeva M, Fauquet CM, Taylor N (2015) Improvements in Agrobacterium-mediated transformation of cassava (Manihot esculenta Crantz) for large-scale production of transgenic plants. Plant Cell Tiss Organ Cult 121:591-603

12. Chetty CC, Rossin CB, Gruissem W, Vanderschuren H, Rey ME (2013) Empowering biotechnology in southern Africa: establishment of a robust transformation platform for the production of transgenic industry-preferred cassava. N Biotechnol 25:136-143

13. Cosgrove DJ (1993) Wall extensibility: its nature, measurement and relationship to plant cell growth. New Phytol 124:1-23

14. Curtis MD, Grossniklaus U (2003) A gateway cloning vector set for high-throughput functional analysis of gene in planta. Plant Physiol 133:462-469

15. Driver JA, Kuniyuki AN (1984) In vitro propagation of Paradox walnut rootstock. Hortic Sci 19:507-509

16. Doyle JJ, Doyle JL (1987) A rapid DNA isolation procedure for small quantities of fresh leaf tissue. Phytochem Bull 19:11-15

17. Funck D, Baumgarten L, Stift M, von Wirén N, Schönemann L (2020) Differential Contribution of P5CS Isoforms to Stress Tolerance in Arabidopsis. Front Plant Sci 11:565134

18. Gresshoff P, Doy C (1974) Derivation of a haploid cell line from Vitis vinifera and the importance of the stage of meiotic development of the anthers for haploid culture of this and other genera. Z Pflanzenphysiol 73:132-141

19. Gyves EM, Picarella ME, Ruiu F, Silva J, Rouphael Y, Muleo R, Rugini E (2010) Inhibition of Agrobacterium tumefaciens Growth by Silver Nitrate. Int J Plant Dev Biol 4:64-67

20. Hummel AW, Chauhan RD, Cermak, Mutka AM, Vijayaraghavan A, Boyher A, Starker CG, Bart R, Voytas DF, Taylor NJ (2018) Allele exchange at the EPSPS locus confers glyphosate tolerance in cassava. Plant Biotechnol J 16:1275-1282

21. Hood EG, Chilton WS, Chilton M-D, Fraley RT (1986) T-DNA and opine synthetic loci in tumors incited by Agrobacterium tumefaciens A281 on Soybean and Alfalfa plants. J Bacteriol 168:1283-1290

22. Ikeuchi M. Sugimoto K. Iwase A (2013) Plant callus: mechanisms of induction and repression. Plant Cell 25:3159-3173

23. Ji H, Wang Y, Cloix C, Li K, Jenkins GI, Wang S, Shang Z, Shi Y, Yang S, Li X (2015) The Arabidopsis RCC1 Family Protein TCF1 Regulates Freezing Tolerance and Cold Acclimation through Modulating Lignin Biosynthesis. PLoS Genet 11:e1005471

24. Krishnamurthy P, Vishal B, Ho WJ, Lok FCJ, Lee FSM, Kumar PP (2020) Regulation of a Cytochrome P450 Gene CYP94B1 by WRKY33 Transcription Factor Controls Apoplastic Barrier Formation in Roots to Confer Salt Tolerance. Plant Physiol 184:2199-2215

25. Li Y, Darley CP, Ongaro V, Fleming A, Schipper O, Baldauf SL, McQueen-Mason SJ (2002) Plant expansins are a complex multigene family with an ancient evolutionary origin. Plant Physiol 128:854-864

26. Liu J, Zheng Q, Ma Q, Gadidasu KK, Zhang P (2011) Cassava genetic transformation and its application in breeding. J Integr Plant Biol 535:52-69

27. Ma Q, Zhou W, Zhang P (2015) Transition from somatic embryo to friable embryogenic callus in cassava: dynamic changes in cellular structure, physiological status, and gene expression profiles. Front Plant Sci 6:824

28. Malik Al, Kongsil P, Nguyễn VA, Ou W, Sholihin, Srean P, Sheela MN, Becerra López-Lavalle LA, Utsumi Y, Lu C, Kittipadakul P, Nguyễn HH, Ceballos H, Nguyễn TH, Selvaraj Gomez M, Aiemnaka P, Labarta R, Chen S, Amawan S, Sok S, Youabee L, Seki M, Tokunaga H, Wang W, Li K, Nguyễn HA, Nguyễn V, Hàm LH, Ishitani M (2020) Cassava breeding and agronomy in Asia: 50 years of history and future directions. Breed Sci 70:145-166

29. Murashige T, Skoog S (1962) A revised medium for rapid growth and bioassays with tabacco tissue cultures. Physiol Plantarum 15:473-497

30. Ntui VO, Kong K, Khan RS, Igawa T, Janavi GJ, Rabindran R, Nakamura I, Mii M (2015) Resistance to Sri Lankan Cassava Mosaic Virus (SLCMV) in Genetically Engineered Cassava cv. KU50 through RNA Silencing. PLoS ONE 10:e0120551

31. Nyaboga EN, Njiru JM, Tripathi L (2015) Factors influencing somatic embryogenesis, regeneration, and Agrobacterium-mediated transformation of cassava (Manihot esculenta Crantz) cultivar TME14. Front Plant Sci 6:411

32. Odipio J, Alicai T, Ingelbrecht I, Nusinow DA, Bart R, Taylor NJ (2017) Efficient CRISPR/Cas9 genome editing of phytoene desaturase in cassava. Front Plant Sci 8:1780

33. Park J, Cui Y, Kang B-H (2015) AtPGL3 is an Arabidopsis BURP domain protein that is localized to the cell wall and promotes cell enlargement. Front Plant Sci 6:412

34. Peters C, Li M, Narasimhan R, Roth M, Welti R, Wang X (2010) Nonspecific phospholipase C NPC4 promotes responses to abscisic acid and tolerance to hyperosmotic stress in Arabidopsis. Plant Cell 22:2642-2659

35. Rehman HM, Nawaz MA, Shah ZH, Ludwig-Müller J, Chung G, Ahmad MQ, Yang SH, Lee SI (2018) Comparative genomic and transcriptomic analyses of Family-1 UDP glycosyltransferase in three Brassica species and Arabidopsis indicates stress-responsive regulation. Sci Rep 8:1875

36. Saelim L, Phansiri S, Suksangpanomrung M, Netrphan S, Narangajavana J (2009) Evaluation of a morphological marker selection and excision system to generate marker-free transgenic cassava plants. Plant Cell Rep 28:445-455

Page $7 / 11$ 
37. Seki M, Tokunaga H, Utsumi C et al (2018) Advancement of Asian Cassava Molecular Breeding towards SDGs. Proceedings of the 18th Science Council of Asia (SCA) Conference "Role of Science for Society: Strategies towards SDGs in Asia". http://www.scj.go.jp/en/sca/. Accessed Dec 2018

38. Southern Ed (2006) Southern blotting. Nat Protoc 1:518-525

39. Takenaka Y, Nakano S, Tamoi M, Sakuda S, Fukamizo T (2009) Chitinase gene expression in response to environmental stresses in Arabidopsis thaliana: chitinase inhibitor allosamidin enhances stress tolerance. Biosci Biotechnol Biochem 73:1066-1071

40. Taylor NJ, Edwards M, Kiernan RJ, Davey CDM, Blakesley D, Henshaw GG (1996) Development of friable embryogenic callus and embryogenic suspension culture systems in cassava (Manihot esculenta Crantz). Nat Biotechnol 14:726-730

41. Taylor N, Gaitán-Solís E, Moll T, Trauterman B, Jones T, Pranjal A, Trembley C, Abernathy V, Corbin D, Fauquet CM (2012) A High-throughput platform for the production and analysis of transgenic cassava (Manihot esculenta) plants. Tropical Plant Biol 5:127-139

42. Urano K, Yoshiba Y, Nanjo T, Ito T, Yamaguchi-Shinozaki K, Shinozaki K (2004) Arabidopsis stress-inducible gene for arginine decarboxylase AtADC2 is required for accumulation of putrescine in salt tolerance. Biochem Biophys Res Commun 313:369-375

43. Utsumi Y, Tanaka M, Kurotani A, Yoshida T, Mochida K, Matsui A, Ishitani M, Sraphet S, Whankaew S, Asvarak T, Narangajavana J, Triwitayakorn K, Sakurai T, Seki M (2016) Cassava (Manihot esculenta) transcriptome analysis in response to infection by the fungus Colletotrichum gloeosporioides using an oligonucleotide-DNA microarray. J Plant Res 129:711-726

44. Utsumi Y, Utsumi C, Tanaka M, Ha VT, Matsui A, Takahashi S, Seki M (2017) Formation of friable embryogenic callus in cassava is enhanced under conditions of reduced nitrate, potassium and phosphate. PLoS One 12:e0180736

45. Wakabayashi K, Hoson T, Huber DJ (2003) Methyl de-esterification as a major factor regulating the extent of pectin depolymerization during fruit ripening: a comparison of the action of avocado (Persea americana) and tomato (Lycopersicon esculentum) polygalacturonases. J Plant Physiol 160:667-673

46. Willats WG, Orfila C, Limberg G, Buchholt HC, van Alebeek GJ, Voragen AG, Marcus SE, Christensen TM, Mikkelsen JD, Murray BS, Knox JP (2001) Modulation of the degree and pattern of methyl-esterification of pectic homogalacturonan in plant cell walls. Implications for pectin methyl esterase action, matrix properties, and cell adhesion. J Biol Chem 276:19404-19413

47. Zainuddin IM, Schlegel K, Gruissem W, Vanderschuren H (2012) Robust transformation procedure for the production of transgenic farmer-preferred cassava landraces. Plant Meth 8:24

48. Zhang P, Phansiri S, Puonti-Kaerlas J (2001) Improvement of cassava shoot organogenesis by the use of silver nitrate in vitro. Plant Cell Tissue Organ Cult 67:47-54

\section{Tables}

Table 1. Efficiency of OEC and FEC induction in 60444 and KU50

\begin{tabular}{|c|c|c|c|c|c|c|c|c|c|c|}
\hline & \multicolumn{5}{|l|}{60444} & \multicolumn{5}{|l|}{ KU50 } \\
\hline & $\begin{array}{l}\text { Number } \\
\text { of } \\
\text { axillary } \\
\text { buds }\end{array}$ & $\begin{array}{l}\text { Number of } \\
\text { OEC } \\
\text { induced a }\end{array}$ & $\begin{array}{l}\text { Number } \\
\text { of FEC } \\
\text { induced }^{b}\end{array}$ & $\begin{array}{l}\text { Efficiency of } \\
\text { OEC } \\
\text { induction } \\
(\%)^{c}\end{array}$ & $\begin{array}{l}\text { Efficiency of } \\
\text { FEC } \\
\text { induction } \\
(\%)^{d}\end{array}$ & $\begin{array}{l}\text { Number } \\
\text { of } \\
\text { axillary } \\
\text { buds }\end{array}$ & $\begin{array}{l}\text { Number of } \\
\text { OEC } \\
\text { induced }{ }^{a}\end{array}$ & $\begin{array}{l}\text { Number } \\
\text { of FEC } \\
\text { induced }^{b}\end{array}$ & $\begin{array}{l}\text { Efficiency of } \\
\text { OEC } \\
\text { induction } \\
(\%)^{c}\end{array}$ & $\begin{array}{l}\text { Efficiency of } \\
\text { FEC } \\
\text { induction } \\
(\%)^{d}\end{array}$ \\
\hline exp1 & 106 & 93 & 69 & 87.7 & 65.1 & 96 & 45 & 10 & 46.9 & 10.4 \\
\hline exp2 & 112 & 45 & 31 & 40.2 & 27.7 & 125 & 74 & 14 & 59.2 & 11.2 \\
\hline exp3 & 100 & 85 & 58 & 85.0 & 58.0 & 71 & 47 & 4 & 66.2 & 5.6 \\
\hline exp4 & - & - & - & - & - & 135 & 90 & 26 & 66.7 & 19.3 \\
\hline Average & 106 & 74 & 53 & 71.0 & 50.3 & 107 & 64 & 14 & 59.8 & 11.5 \\
\hline S.D. & 6 & 26 & 20 & 26.7 & 19.9 & 29 & 22 & 9 & 9.2 & 5.4 \\
\hline
\end{tabular}

a When multiple OEC were observed from one axillary bud, the number of OEC induced was counted as one.

b When multiple FEC were induced from OEC induced from one bud, the number of FEC induced was counted as one.

${ }^{c}$ Efficiency of OEC induction (\%) $=$ (Number of OEC/Number of axillary bud explants)

${ }^{d}$ Efficiency of FEC induction (\%) = (Number of FEC/Number of axillary bud explants) 
Table 2. Transformation efficiency of 60444 and KU50

60444 stage embryo per $1 \mathrm{~g}$ of FEC

\begin{tabular}{|c|c|c|c|c|c|c|}
\hline & $\begin{array}{l}\text { Number of cotyledon- } \\
\text { stage embryo per } 1 \mathrm{~g} \text { of } \\
\text { FEC }\end{array}$ & $\begin{array}{l}\text { Number of GFP } \\
\text { positive plantlets per } 1 \\
\mathrm{~g} \text { of FEC }\end{array}$ & $\begin{array}{l}\text { Transformation } \\
\text { efficiency }(\%)\end{array}$ & $\begin{array}{l}\text { Number of cotyledon- } \\
\text { stage embryos per } 1 \mathrm{~g} \\
\text { of FEC }\end{array}$ & $\begin{array}{l}\text { Number of GFP } \\
\text { positive plantlets per } 1 \\
\mathrm{~g} \text { of FEC }\end{array}$ & $\begin{array}{l}\text { Transformation } \\
\text { efficiency }(\%)\end{array}$ \\
\hline exp1 & 45 & 19 & 42 & 232 & 60 & 26 \\
\hline $\exp 2$ & 54 & 30 & 57 & 121 & 32 & 26 \\
\hline exp3 & 77 & 38 & 49 & 136 & 16 & 12 \\
\hline $\exp 4$ & 54 & 13 & 24 & 107 & 41 & 38 \\
\hline $\exp 5$ & 59 & 30 & 51 & 159 & 15 & 9 \\
\hline Average & 58 & 26 & 45.0 & 151 & 33 & 22.0 \\
\hline S.D. & 12 & 10 & 13.0 & 49 & 19 & 12.0 \\
\hline
\end{tabular}

KU50

Table 3. Differentially expressed genes between KU50 FEC and 60444 FEC by the incubation on FIM

\begin{tabular}{|c|c|c|c|c|c|c|c|c|c|}
\hline ProbeName & $\begin{array}{l}\text { q value } \\
\text { by } \mathrm{BH} \\
\text { method }\end{array}$ & $\begin{array}{l}\mathrm{p} \\
\text { value }\end{array}$ & $\begin{array}{l}\log _{2} \\
\text { Fold } \\
\text { change } \\
\text { ([KU50 } \\
\text { FEC on } \\
\text { FIM] - } \\
{[60444} \\
\text { FEC on } \\
\text { FIM]) }\end{array}$ & $\begin{array}{l}\text { Encoded Proteins/other features } \\
\text { a }\end{array}$ & $\begin{array}{l}\text { Gene } \\
\text { name }\end{array}$ & AGI code ${ }^{b}$ & $\begin{array}{l}\mathrm{E}- \\
\text { value }\end{array}$ & $\begin{array}{l}\text { Cassava gene } \\
\text { model }^{c}\end{array}$ & Ref. \\
\hline RknMes02_053373 & $\begin{array}{l}7.90 \mathrm{E}- \\
08\end{array}$ & $\begin{array}{l}2.50 \mathrm{E}- \\
09\end{array}$ & 7.0 & non-specific phospholipase C4 & NPC4 & AT3G03530.1 & 0 & Manes.09G131600 & $\begin{array}{l}\text { Utsun } \\
\text { et al. } \\
2017\end{array}$ \\
\hline RknMes02_027216 & $\begin{array}{l}1.30 \mathrm{E}- \\
05\end{array}$ & $\begin{array}{l}2.50 \mathrm{E}- \\
06\end{array}$ & 2.4 & $\begin{array}{l}\text { phosphoenolpyruvate } \\
\text { carboxylase kinase } 2\end{array}$ & PPCK2 & AT3G04530.1 & 0 & Manes.08G138300 & $\begin{array}{l}\text { Utsun } \\
\text { et al. } \\
2017\end{array}$ \\
\hline RknMes02_025148 & $\begin{array}{l}2.30 \mathrm{E}- \\
05\end{array}$ & $\begin{array}{l}5.30 \mathrm{E}- \\
06\end{array}$ & 2.4 & $\begin{array}{l}\text { Plant invertase/pectin } \\
\text { methylesterase inhibitor } \\
\text { superfamily }\end{array}$ & & AT4G02320.1 & 0 & Manes.01G221700 & $\begin{array}{l}\text { Ma et } \\
\text { al. } \\
2015\end{array}$ \\
\hline RknMes02_039364 & $\begin{array}{l}3.60 \mathrm{E}- \\
06\end{array}$ & $\begin{array}{l}5.10 \mathrm{E}- \\
07\end{array}$ & 2.1 & acyl-CoA sterol acyl transferase & ASAT1 & AT3G51970.1 & 0 & Manes.10G134500 & $\begin{array}{l}\text { Utsun } \\
\text { et al. } \\
2017\end{array}$ \\
\hline RknMes02_033632 & $\begin{array}{l}1.30 \mathrm{E}- \\
05\end{array}$ & $\begin{array}{l}2.60 \mathrm{E}- \\
06\end{array}$ & 1.4 & $\begin{array}{l}\text { xyloglucan } \\
\text { endotransglucosylase/hydrolase } \\
16\end{array}$ & XTH16 & AT3G23730.1 & 0 & Manes.05G199600 & $\begin{array}{l}\text { Utsun } \\
\text { et al. } \\
2017\end{array}$ \\
\hline RknMes02_048202 & $\begin{array}{l}9.10 \mathrm{E}- \\
06\end{array}$ & $\begin{array}{l}1.70 \mathrm{E}- \\
06\end{array}$ & 1.4 & $\begin{array}{l}\text { Auxin-responsive GH3 family } \\
\text { protein }\end{array}$ & $\mathrm{GH} 3.17$ & AT1G28130.1 & 0 & Manes.08G100100 & $\begin{array}{l}\text { Ma et } \\
\text { al. } \\
2015\end{array}$ \\
\hline RknMes02_014383 & $\begin{array}{l}2.60 \mathrm{E}- \\
06\end{array}$ & $\begin{array}{l}3.40 \mathrm{E}- \\
07\end{array}$ & 1.1 & glutamate decarboxylase 4 & GAD4 & AT2G02010.1 & $\begin{array}{l}1.00 \mathrm{E}- \\
38\end{array}$ & Manes.17G091400 & $\begin{array}{l}\text { Ma et } \\
\text { al. } \\
2015\end{array}$ \\
\hline RknMes02_022298 & $\begin{array}{l}5.50 \mathrm{E}- \\
07\end{array}$ & $\begin{array}{l}4.00 E- \\
08\end{array}$ & 1.1 & $\begin{array}{l}\text { phosphoenolpyruvate } \\
\text { carboxylase kinase } 1\end{array}$ & PPCK1 & AT1G08650.1 & $\begin{array}{l}8.00 \mathrm{E}- \\
39\end{array}$ & Manes.03G164500 & $\begin{array}{l}\text { Utsun } \\
\text { et al. } \\
2017\end{array}$ \\
\hline RknMes02_048606 & $\begin{array}{l}1.20 \mathrm{E}- \\
04\end{array}$ & $\begin{array}{l}3.80 \mathrm{E}- \\
05\end{array}$ & -1.6 & $\begin{array}{l}\text { Leucine-rich repeat (LRR) family } \\
\text { protein }\end{array}$ & & AT4G06744.1 & 0 & Manes.18G040900 & $\begin{array}{l}\text { Utsun } \\
\text { et al. } \\
2017\end{array}$ \\
\hline
\end{tabular}

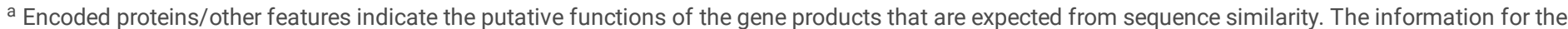
$\mathrm{NCBI}$ protein reference sequence with the highest sequence similarity with the probes is shown.

b The information for AGI locus ID with the highest sequence similarity with the probe is shown.

c The information for cassava gene code with the highest sequence similarity with the probe is shown.

\section{Figures}



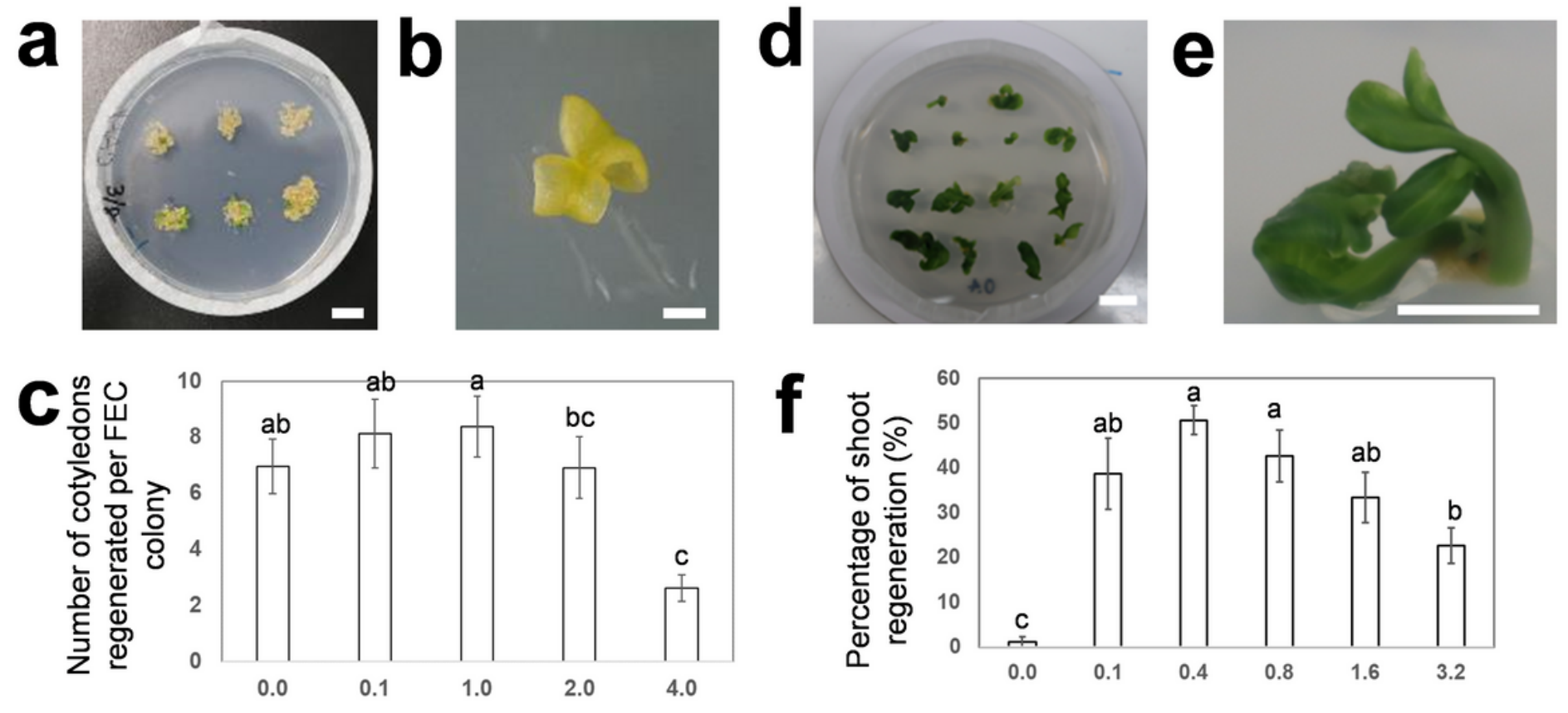

NAA concentration $(\mathrm{mg} / \mathrm{L})$

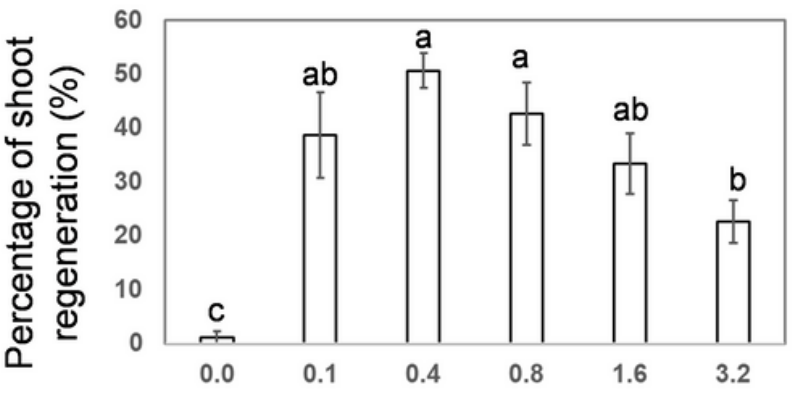

\section{BAP concentration $(\mathrm{mg} / \mathrm{L})$}

\section{Figure 1}

Effect of NAA and BAP concentrations on somatic embryo maturation and shoot regeneration efficiency from FEC of KU50. a Six FEC colonies were culture on MS-based media supplemented with different NAA concentrations and cultivated for two months. The number of cotyledon-stage embryos produced per colony was assessed after 4 weeks. Bar represents $1 \mathrm{~cm}$. b Early cotyledon-stage embryo recovered from FEC. Bar represents $1 \mathrm{~mm}$. c Regeneration efficiency from KU50 FEC to cotyledon-stage embryos cultured on MS-based media with various NAA concentrations. Mean and SE were calculated based on the data from four biological replicates with FEC 6 colonies per plate defined as a biological replicate. $d$ Fifteen cotyledon-stage embryos were cultured MS-based media supplemented with different BAP concentrations and cultivated for two months. The number of shoots induced per one plate was counted for the evaluation. Bar represents $1 \mathrm{~cm}$. e Shoot of KU50 germinating from late cotyledon stage embryo cultured on media containing BAP. Bar represents $0.5 \mathrm{~cm}$. $f$ Shoot regeneration efficiency from cotyledon-stage embryos cultured on MS-based media supplemented with various concentrations of BAP. Means and SE were calculated based on data from four biological replicate with15 cotyledon-stage embryos per plate was defined as a biological replicate. Each bar and the vertical line on Figs. $1 \mathrm{c}$ and $1 \mathrm{f}$ represent the mean and standard deviation from 4 biological replicates, respectively. Letters above the bars indicate significant differences among the treatments. Bars with the same letter indicate that they are not significantly different $(P \leq 0.05)$. The $p$-value was calculated by oneway ANOVA with Scheff's multiple comparisons test. 

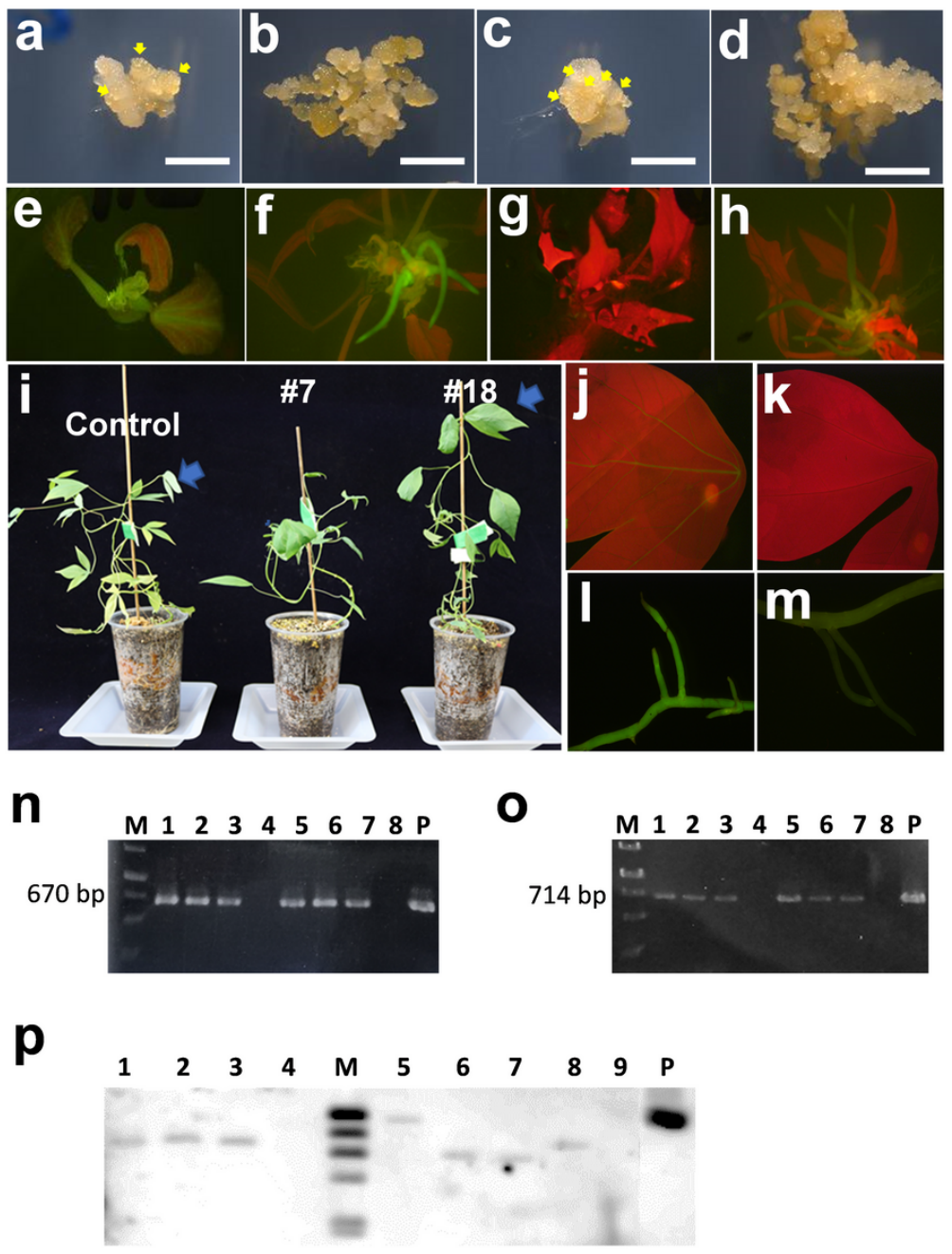

Figure 2

Agrobacterium-mediated transformation of KU50. a Globular and torpedo-stage embryos (arrowed) developing from FEC of 60444. b Friable Embryogenic Calli (FEC) from 60444 induced on FIM media. c Globular and torpedo-stage embryos (arrowed) developing from FEC of KU50. d FEC from KU50 induced on FIM media. e GFP expression observable from regenerating transformed KU50 plantlet. $\mathrm{f} \mathrm{GFP} \mathrm{expression} \mathrm{observation} \mathrm{in} \mathrm{roots} \mathrm{of} \mathrm{transformed} \mathrm{KU50} \mathrm{plantlet.} \mathrm{g}$ No GFP fluorescence observable from non-transgenic KU50 plantlet. h No GFP fluorescence in root of non-transgenic KU50 plantlet. i Transgenic (\#7 and \#18) and non-transgenic (control) KU50 plants growing on soil for 2 months at $28^{\circ} \mathrm{C}$ in the greenhouse. j GFP fluorescence in the leaf (shown by the arrow in Fig. $1 \mathrm{i}$ ) of transgenic plant \#18 k No GFP fluorescence seen in the leaf of non-transgenic (control) I GFP fluorescence observed in the root of transgenic plant \#18. $\mathrm{m}$ No GFP fluorescence in the root of non-transgenic (control) plant. Bars represent $5 \mathrm{~mm}$. $\mathrm{n}$ PCR confirmation for transgenic nature of mgfp6 gene in genome DNA extracted from transformed KU50 plants. o PCR confirmation of the integration of hpt gene in genomic DNA from transgenic plants. Lane M: DNA molecular marker; Lane P: pMDC111 plasmid DNA; Lanes 1 to 3: GFP transgenic lines \#7, \#8 and \#18 from KU50; Lane 4: non-transgenic KU50; Lane 5 to 7: GFP transgenic lines \#2, \#3 and \#6 from 60444; Lane 8: non-transgenic 60444. p Southern blot of genomic DNA from cassava plants. Lane M: DIG-labeled DNA molecular marker (the size of molecular markers is 23,130 bp, 9,416 bp, 6,557 bp, 4,361 bp, 2,322 bp, 2,027 bp from the upper); Lane 1 to 3 : GFP transgenic lines \#2, \#3 and \#6 from 60444; Lane 4: non transgenic 60444; Lane 5 to 8: GFP transgenic lines \#7, \#8, \#18 and \#19 of KU50; Lane 9: non transgenic KU50; Lane P: pMDC111 plasmid DNA as positive control. Genomic DNA from transgenic and non-transgenic cassava was digested with HindIII.

\section{Supplementary Files}

This is a list of supplementary files associated with this preprint. Click to download.

- SFigure1.tif

- SFigure2.tif

- SFigure3.tif

- SFigure4.tif

- SFigure5.tif

- Utsumietal.STablesfinal.xIsx 